\title{
A Case of Tooth Aspiration During Dental Extraction: Could It Be Prevented by Sedation Practices?
}

\author{
Diş Çekimi Sırasında Gelişen Diş Aspirasyonu: Sedasyon Uygulamaları ile Önlenebilir Mi?
}

\author{
(D) Nagihan Çakır1, (D) Okşan Derinöz Güleryüz², (D) Yasemin Men Atmaca² \\ ${ }_{1}^{1}$ Gazi University Faculty of Medicine, Department of Child Health and Diseases, Ankara, Turkey \\ ${ }^{2}$ Gazi University Faculty of Medicine, Department of Pediatric Emergency Medicine, Ankara, Turkey
}

\section{Abstract}

One of the most common life-threatening emergencies in children is foreign body aspiration, which occurs when children take in small parts of food and toys. Tooth aspiration or ingestion is an unusual circumstance that happens as a result of aspiration or swallowing of a tooth that is broken after iatrogenic or during maxillofacial trauma, especially during endotracheal intubation. Further, tooth aspiration after tooth extraction is very rare. Here a 10-year-old patient with cough and dyspnoea one day after tooth extraction was presented to the pediatric emergency due to a rare foreign body in the airway and a rare complication after tooth extraction. In addition, sedation and anaesthesia applications used during the dental procedure were discussed, and the question was also whether this complication could be prevented.

Keywords: Aspiration, children, tooth, tooth extraction, sedation

\section{Introduction}

Closure/blockage of airway with an object is a life-threatening situation that needs early diagnosis and treatment. The severity of the condition varies according to the airway blockage location and its complete or partial character.

Tooth aspiration/ingestion is a rare condition that is most frequently caused by aspiration or swallowing of a tooth that is iatrogenically broken during endotracheal intubation or after blunt maxillofacial trauma, with $0.4 \%$ reported incidence. ${ }^{1,2}$

We present this case because the tooth is not a common foreign object seen in the airway, and it is also an uncommon situation to have complications after tooth extraction.

\section{Öz}

Yabancı cisim aspirasyonu, çocuklarda yaşamı tehdit eden en sık görülen acil durumlardan biridir. Aspirasyonun en sık nedeni, çocukların ağızlarına aldıkları küçük yiyecek parçaları ve oyuncaklardır. Dişin aspirasyonu veya yutulması, nadir görülen bir durumdur; sıklıkla iyatrojenik veya maksillofasiyal travma sırasında, özellikle endotrakeal entübasyon sırasında, kırılan dişin aspirasyonu veya yutulması sonucu oluşur. Diş çekimi sonrası diş aspirasyonu ise oldukça nadirdir. Burada, diş çekiminden bir gün sonra öksürük ve nefes darlığı şikayeti ile çocuk acil servise başvuran 10 yaşında bir hasta dişin hava yolunda nadir görülen bir yabancı cisim ve diş aspirasyonunun diş çekimi sonrası gelişen nadir bir komplikasyon olması nedeniyle sunuldu. Ayrıca bu olgu ile dental işlem sırasında kullanılan sedasyon ve anestezi uygulamaları tartışılmış ve bu komplikasyonun önlenip önlenemeyeceği sorusu da tartışılmıştır.

Anahtar Kelimeler: Aspirasyon, çocuk, diş, diş çekimi, sedasyon
In addition, we want to address sedation or anaesthesia applications during tooth treatment.

\section{Case Report}

A 10-year-old healthy male patient was admitted to hospital with coughing and breathing difficulty complaints. The day before, he was admitted to the dentist for treatment of tooth decay, and during surgery under local anaesthesia (LA), he was very agitated, and the tooth was broken and not completely extracted. It was also discovered that during the surgery, the patient coughed too much and was discharged by the dentist after the procedure. The dentist advised the family

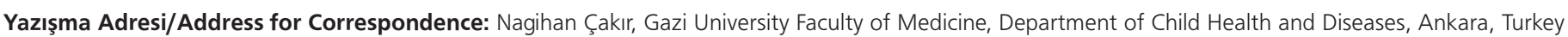
E-posta: drnagihansener@gmail.com ORCID ID: orcid.org/0000-0001-5488-5324

Geliş Tarihi/Received: 30.11.2019 Kabul Tarihi/Accepted: 12.02.2020

- Copyright 2021 by Society of Pediatric Emergency and Intensive Care Medicine

Journal of Pediatric Emergency and Pediatric Intensive Care published by Galenos Yayınevi. 
of the patient that "he might have swallowed the tooth, which could be removed through the gaita". Furthermore, the patient was hospitalised 36 hours after the surgery with increased coughing, wheezing and dyspnoea complaints.

Besides respiratory rate, vital signs were normal. In the left centre lung areas, his respiratory sounds were lower, expiration was long and substernal and subcostal retraction was available. In the chest radiography, a radio-opaque tooth part was observed in the left parasternal-left main bronchus compatible area (Figure 1, 2). Further, rigid bronchoscopy was performed under general anaesthesia. A tooth part was detected in the left main bronchus. On the first postoperative day, the patient was discharged. The forensic system related to this case has been registered.

\section{Discussion}

During extraction, aspiration of the whole or part of the tooth is a rare. ${ }^{2,3}$ Loss of the extracted tooth during the operation primarily makes us consider that the tooth could be swallowed. In several of the recorded cases, it was observed that this condition was expressed by the dentist to the patient or relatives. ${ }^{3,4}$ There is a risk of tooth aspiration in patients with neurological disease or maxillofacial trauma and those undergoing oral interventions under sedation. Aspiration can occur even in healthy individuals with deep inspiration during oral intervention. ${ }^{5,6}$

In order to prevent the development of complications and to keep the child immobilised during the procedure, local/general anaesthesia or conscious sedation may be considered. Dental procedures are usually performed under LA. ${ }^{7,8}$ Conscious sedation and analgesia applications outside the operating room could be an appropriate option for our patient. However, it should be remembered that sedation during the procedure may reduce protective cough and swallowing reflex.

According to the British Society of Paediatric Dentistry Guidelines for dental general anaesthesia, indications in used reasons are severe pulpitis requiring urgent relief if the child
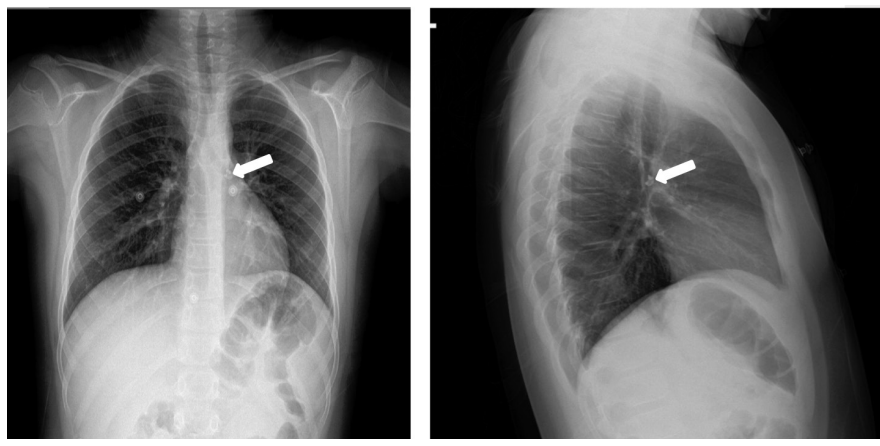

Figure 1, 2. Anteroposterior and lateral chest radiography. Radiopaque density in the left main bronchus (white arrow) does not have the intellectual capacity to cope with treatment under LA, single or multiple extractions in a child under the age of 4 years, biopsy of a hard or soft tissue lesion, allergy reaction to $L A$, acute soft tissue swelling requiring removal of the infected teeth and their surgical drainage, symptomatic teeth causing pain in more than two quadrants, debridement and suturing of orofacial wounds, moderately traumatic or complex extractions and extraction of four carious first permanent molars, in which the procedure may be difficult or may compromise patient cooperation. ${ }^{9}$

If sedation is to be applied, a dampened pad should be located on the oropharynx to prevent intraoral bleeding, secretion increase and aspiration of fluids such as washing solution. 2,7 Airway protective reflex decreases as the sedation degree increases and the possibility of airway obstruction or foreign object aspiration increases. ${ }^{10}$ Moreover, LA was preferred as our patient was old enough to make cooperation possible. However, the patient was very agitated and moved too much during the procedure, making it difficult for the dentist to perform the procedure. This caused the breaking and aspiration of the tooth during the procedure. General anaesthesia and conscious sedation could be preferred due to the clinical condition of our patient. However, it should be kept in mind that sedation may increase the risk of aspiration and should be applied after taking necessary airway precautions.

Perrott et al. ${ }^{11}$ showed a complication rate in $0.4 \%$ with LA, 1.5\% with general anaesthesia or deep sedation and $0.9 \%$ with conscious sedation. The study included types of complications such as laryngospasm, bronchospasm or other respiratory complications, gastrointestinal, cardiac arrhythmia, syncope, seizure, neurologic impairment, long-term recovery and peripheral vascular injuries.

Benzodiazepines, narcotics, barbiturates and hypnotics can be used in sedation. In addition, in dental procedures, benzodiazepines can be used safely. They have anxiolytic, strongly anticonvulsant, sedative and muscle-relaxing characteristic but have no analgesic effects. ${ }^{7,8}$ Opioids (morphine, codeine and synthetic fentanyl) are analgesic and anxiolytic, which may cause bradycardia and respiratory depression. In intravenous conscious sedation, the use of amnestic and sedative-acting midazolam and analgesicacting fentanyl is frequently used. Due to its analgesic and amnestic characteristics, ketamine can be used intravenously and intramuscularly. Also, propofol can be used in regional anaesthesia for anaesthesia induction and sedation. ${ }^{12}$

\section{Conclusion}

During dental procedure, tooth aspiration is a rare situation. After the procedure, all extracted teeth and used tools 
should be counted. It should be kept in mind that not only can the missing teeth and materials be swallowed, but they can also enter the airway. In the event of sudden onset of cough during and after the procedure, the patient should be immediately referred to the emergency department for foreign body aspiration. Although sedation is recommended to facilitate the procedure during tooth extraction and to prevent complications, it should be noted that all anaesthetic drugs used can pose a danger to the airway and suppress airway protective reflexes.

\section{Ethics}

Informed Consent: We was approved informed consent from the child's parents.

Peer-review: Externally peer-reviewed.

\section{Authorship Contributions}

Concept: N.Ç., O.D.G., Design: O.D.G., Data Collection or Processing: N.Ç., Analysis or Interpreation: N.Ç., O.D.G., Y.M.A., Literature Search: N.Ç., O.D.G., Y.M.A., Writing: N.Ç., O.D.G.

Conflict of Interest: No conflict of interest was declared by the authors.

Financial Disclosure: The authors declared that this study received no financial support.

\section{References}

1. Xiao WL, Zhang DZ, Wang YH. Aspiration of two permanent teeth during maxillofacial injuries. J Craniofac Surg. 2009;20:558-60.
2. Hou R, Zhou H, Hu K, Ding Y, Yang X, et al. Thorough documentation of the accidental aspiration and ingestion of foreign objects during dental procedure is necessary: review and analysis of 617 cases. Head Face Med. 2016;12:23.

3. Hedblom CA. Foreign Bodies of dental origin in a bronchus pulmonary complication. Ann Surg. 1920;71:568-80.

4. Ospina JC, Ludemann JP. Aspiration of an extracted molar: case report. J Can Dent Assoc. 2005;71:581-3.

5. Battal F, Aylanç H, Bahadır G, Tekin M, Yıldırım ş. Bronşta diş: Anamnez ve akciğer grafisinin önemi. J ClinExp Invest. 2015;6:199201.

6. Swain SK, SahooS, Sahu MC. From tooth extraction to fatal airway complication in a child-A case report. Egyptian Journal of Ear, Nose, Throat and Allied Sciences. 2016;17:27-9.

7. Karacalar S, Aykac B. Dental girişimlerde genel anestezi uygulamaları. Marmara Medical Journal. 2010;23:400-7.

8. Simsek T, Yılmaz M. Çocuk Hastalardaki Dental Girişimlerde Genel Anestezi ile Sedasyon Tekniğinin Retrospektif Karşılaştırılması. Kocaeli Medical J. 2017;6:59-62.

9. Albadri SS, Lee S, Lee GT, Llewelyn R, Blinkhorn AS, et al. The use of general anaesthesia for the extraction of children's teeth. Results from two UK dental hospitals. Eur Arch Paediatr Dent. 2006;7:110-5.

10. Kim J. Pediatric advanced life support and sedation of pediatric dental patients. J Dent Anesth Pain Med. 2016;16:9-15.

11. Perrott $\mathrm{DH}$, Yuen JP, Andresen RV, Dodson TB. Office-based ambulatory anesthesia: outcomes of clinical practice of oral and maxillofacial surgeons. J Oral Maxillofac Surg. 2003;61:983-95.

12. Koroglu A, Durkan R. Diş hekimliği uygulamalarinda karşilaşilan dental anksiyete sendromunun etiyolojisinin ve tedavi yöntemlerinin değerlendirilmesi. Atatürk Univ Dis Hekim Fak Derg. 2010;3:20512. 